Journal of Advanced Research in Fluid Mechanics and Thermal Sciences

\title{
Energy Profiling for Residential College Buildings
}

\author{
Abdullahi Mohammed Usman¹, Akmal Nizam Mohammed², Mohd Faizal Mohideen², Mas Fawzi \\ Mohd Ali², Kamil Abdullah ${ }^{2,}{ }^{*}$, Juntakan Taweekun ${ }^{3}$ \\ Department of Mechanical Engineering, Modibbo Adama University of Technology (MAUTECH), Yola, Adamawa State, Nigeria \\ Center For Energy and Industrial Environment Studies, Universiti Tun Hussein Onn, 86400 Parit Raja, Johor, Malaysia \\ Department of Mechanical Engineering, Faculty of Engineering, Prince of Songkla University, 90112 Hatyai, Songkhla, Thailand
}

\section{ARTICLE INFO}

Article history:

Received 25 October 2020

Received in revised form 22 February 2021

Accepted 25 February 2021

Available online 1 April 2021

Keywords:

Energy management; building energy index; energy intensity; energy profile; residential college

\section{ABSTRACT}

The present study aims to provide insight on energy profiling of a residential college in public university. The study involves electrical energy monitoring for six months from the month of March until August 2017. The data utilized to derive the average monthly consumption for both semester period and semester break. The consumption during semester break has been recorded to increase as much as $88 \%$ from the consumption during the semester break. The building energy index of the residential college has been recorded to be at $22.90 \mathrm{kWh} / \mathrm{m} 2 /$ year meanwhile the energy intensity was recorded to be at $1,932.08 \mathrm{kWh} /$ occupant/year.

\section{Introduction}

The demand for energy has ever increasing for the last hundred years. Buildings is one of the highest consumer of energy with European building sector has been reported to consumes $40 \%$ of the regional's generated energy [1]. International Energy Outlook report on the current position of the global energy consumption reveals that energy demand will continue to grow by $56 \%$ in-between the year 2010 and 2040 [2]. Malaysia as a developing nation also experience increase in national energy demand to propel her economic growth $[3,4]$. Based on the statistical record released by Malaysia Energy Commission [5], 94\% of generated electricity by the country is derive from the fossil fuels. The figure is expected to be unchanged for the next 10 years which rise environmental issue associated to the climate change [6]. In the United State, the Department of Energy (DoE) has estimated that in 2010 , buildings have consumed $74 \%$ generated electricity and at the same time responsible of emitting $40 \%$ of the carbon dioxide emissions to the environment [7].

It is impossible to operate a building without consuming energy thus, the only way to handle the matter is through implementation of energy management and energy efficiency. Systematic implementation of energy management and energy efficiency can minimize the energy consumption of a building while not jeopardizing the operational requirement of the building [8-10]. In principle,

\footnotetext{
* Corresponding author.

E-mail address:mkamil@uthm.edu.my
}

https://doi.org/10.37934/arfmts.81.2.139145 
the first step in implementation of energy management and energy efficiency is to conduct the energy audit. The activity allows the building owner to evaluate and review the current energy consumption pattern and at the same time identify potential saving measures that can be taken to reduce their energy consumption [11,12]. The findings will provide insight to the energy consumption pattern and can be benchmarked with any other building with similar operational requirement or standards.

However, diversity in terms of building operation has limits the used of general benchmarked value in terms of energy consumption of a buildings. Tremendous efforts have been done to provide the benchmark value particularly for commercial building and residential buildings [13-18]. Although Iwaro and Mwasha [19] has reported that the energy consumption for residential building in Malaysia can be estimated to be between 10 to 20 times lower in comparison with the commercial buildings, there are very limited literatures can be found on residential building and residential college buildings. The present study aims to provide energy profiling for residential college building at public university in Malaysia. The study also includes financial and environmental evaluation associated with energy consumption at residential college building.

\section{Methodology}

\subsection{Background Information}

The present study focuses on residential college located at Universiti Tun Hussein Onn Malaysia (UTHM), Johor, Malaysia namely Kolej Kediaman Tun Dr. Ismail (KKTDI). The residential colleges have modern building design consist of four blocks of student hostels connected to each other and one block of the administration office together with the cafeteria. The four blocks are design to accommodate 1,244 beds depending on the room configuration. Table 1 shows background information of KKTDI and KKTF.

Table 1

Background Information

\begin{tabular}{ll}
\hline & KKTDI \\
\hline Location & $1.86^{\circ} \mathrm{N} 103.09{ }^{\circ} \mathrm{N}$ \\
Gross Floor Area & $28,599.52 \mathrm{~m}^{2}$ \\
Office Floor Area & $220.31 \mathrm{~m}^{2}(0.77 \%)$ \\
Hostel Floor Area & $27,353.60 \mathrm{~m}^{2}(95.64 \%)$ \\
Cafeteria Floor Area & $1,025.61 \mathrm{~m}^{2}(3.59 \%)$ \\
\hline
\end{tabular}

\subsection{Data Collection}

The electricity consumption of KKTDI is measured by SCADA system installed the utility room of each building. The system capable to capture electricity consumption ( $\mathrm{kWh}$ ) at the interval of one second, allowing the production of consumption profile for each residential college for the whole year since October 2016. For the purpose of the present study, electricity consumption from March until August 2017 will be used for the analysis. Other data such as hostel occupancy and floor area are collected manually through site survey which is shown in Table 2. 
Table 2

Occupancy Data

\begin{tabular}{lll}
\hline & KKTDI & \\
& Occupancy & Available Capacity \\
\hline Male & 110 & 622 \\
Female & 229 & 622 \\
Overall & 339 & 1,244 \\
\hline
\end{tabular}

\subsection{Building Energy Index}

One of the energy characteristics that going to be evaluated in the present study is building energy index, $\mathrm{BEI}$. The index representing the electricity consumption of a building for each floor area available in the building. Higher BEI represent higher consumption of electricity per floor area and vice versa. BEI can be determined by Eq. (1)

BEI $\left[\frac{k W h}{m^{2}}\right]=\frac{\text { Electricity Consumption }[k W h]}{\text { Gross FLoor Area }\left[m^{2}\right]}$

\subsection{Energy Intensity}

Another energy characteristic that has been considered in the present study is energy intensity. The energy intensity represent the energy consumes per product or in the case of residential college, energy consumes per occupant. Energy intensity indicates the energy consumption per occupant at the residential college thus allow prediction of future consumption based on forecasted number of occupants. Energy intensity can be determined by Eq. (2)

Energy Intensity $\left[\frac{k W h}{\text { occupant }}\right]=\frac{\text { Electricity Consumption }[k W h]}{\text { Number of Occupants }}$

\section{Results}

\subsection{Monthly Profiling}

Figure 1 shows the monthly electricity consumption profile of KKTDI from March until August 2017. The figure distinguishes high consumption of electricity in the month of March, April and May in comparison with the electricity consumption in the month of Jun, July and August. The obvious different between these two group of month is contributed by the lecture period and semester break period of the university. The month of March, April and May are during the lecture period while, Jun, July and August are during the semester break. In average, during the lecture period, KKTDI is consuming as much $77,439 \mathrm{kWh}$ of electricity monthly in comparison with only $41,107 \mathrm{kWh}$ during the semester break period. The monthly electricity consumption during the lecture period is increased as much as $88 \%$ in comparison with during the semester break.

In terms of financial implication, KKTDI is spending in average RM 28,265.24 monthly during the lecture period in comparison only RM 15,004.06 monthly during the semester break period. Fluctuation in the electricity consumption is more obvious during the semester break period as shown in Figure 1 in comparison with the lecture period. Based on survey during the data collection, the high electricity consumption recorded in the month of Jun and August are contributed by rental of the hostel by third party which is part of the KKTDI strategies for income generation. 


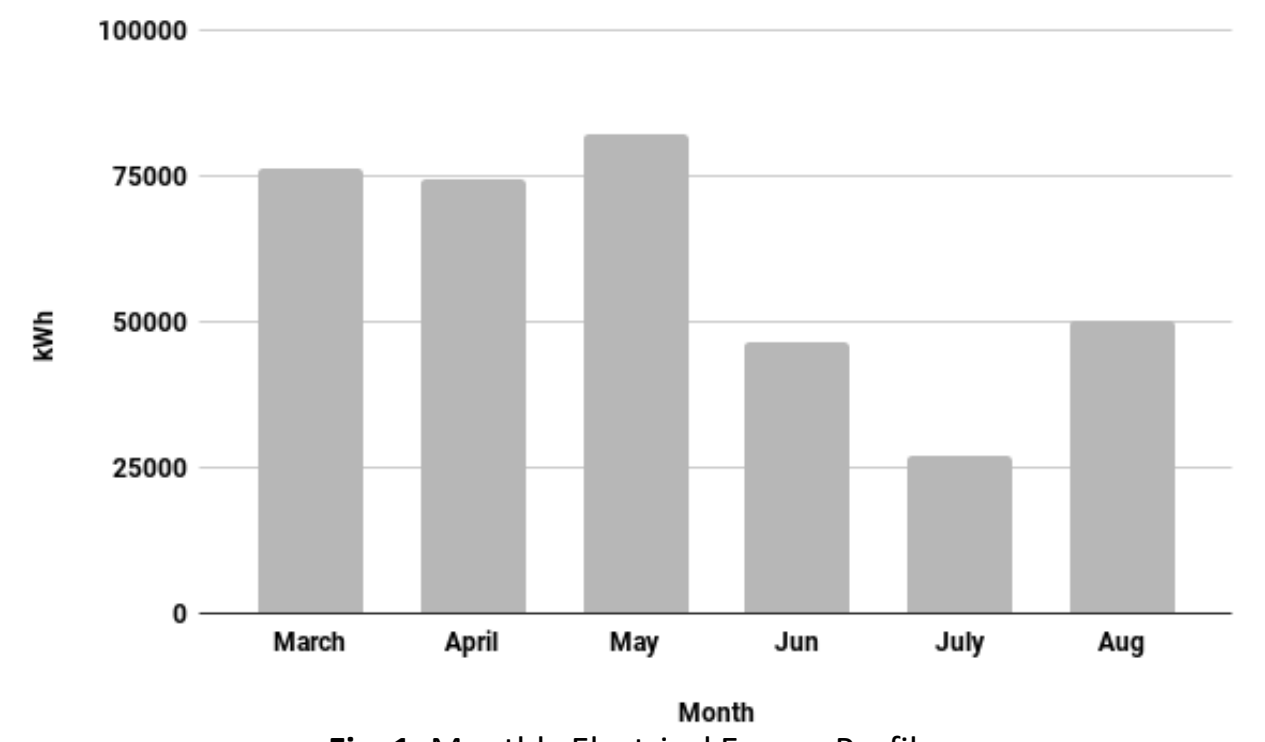

Fig. 1. Monthly Electrical Energy Profile

\subsection{Weekly Profiling}

Figure 2 and Figure 3 show the daily average electricity consumption of KKTDI during the lecture period and semester break period respectively. Both figures show insignificant difference on the electricity consumption throughout the week from Sunday to Saturday in both periods. The highest electricity consumption is recorded on Wednesday at $23,951 \mathrm{kWh}$ and lowest on Saturday at 20,210.42 kWh during the lecture period. Meanwhile for the semester break period, highest electricity consumption is recorded on Sunday at $15,210 \mathrm{kWh}$ and lowest on Wednesday at $12,332 \mathrm{kWh}$. The average daily consumption during the lecture period is recorded to be at 21,482 kWh equivalent to RM 7,841.04 daily. The average daily consumption during semester break is

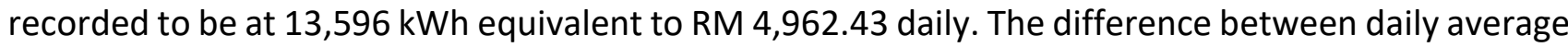
electricity cost between the lecture period and semester break period is recorded to be at RM $2,878.61$ daily which is at $36.71 \%$ difference.

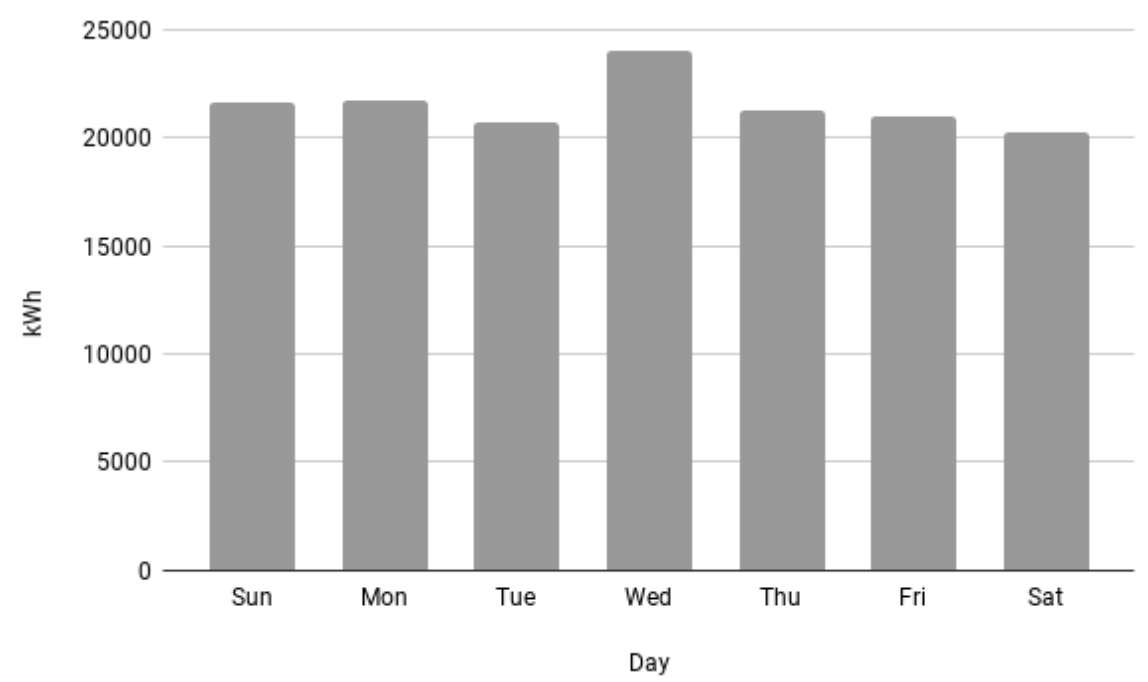

Fig. 2. Daily Average Electricity Consumption During Lecture Period 


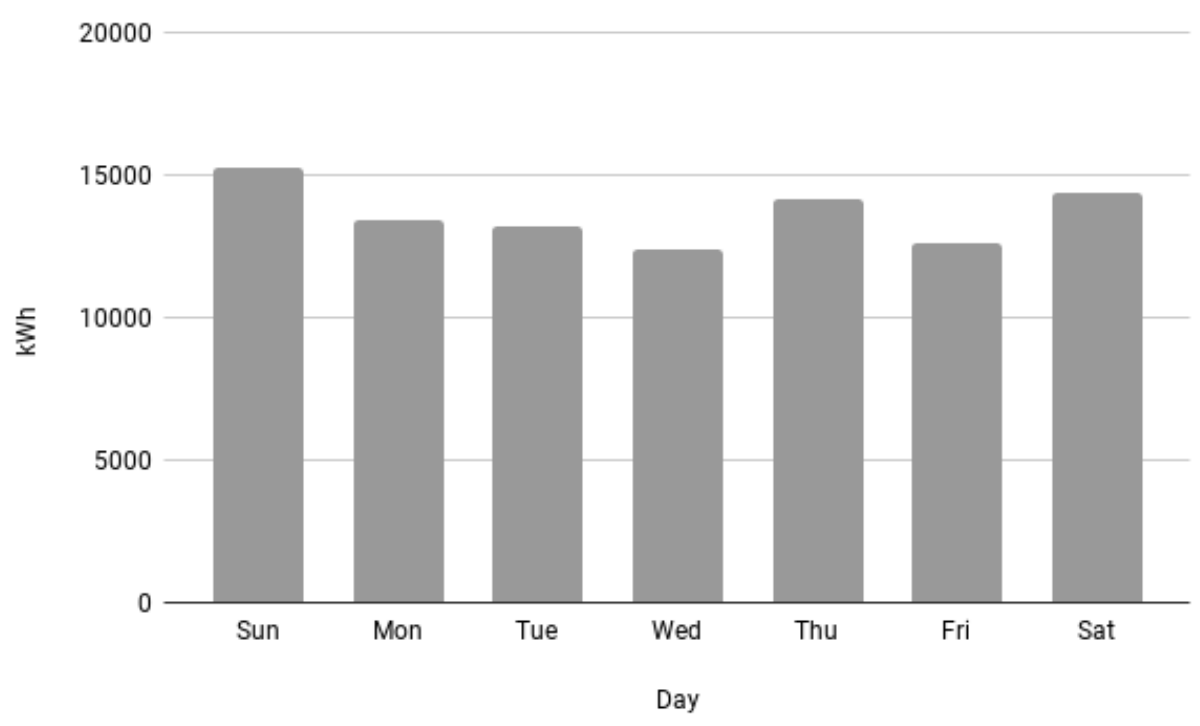

Fig. 3. Daily Average Electricity Consumption During Semester Break Period

Table 3 summaries the monthly and daily average electricity consumption of KKTDI together with associated cost.

Table 3

Summary of Electricity Consumption

\begin{tabular}{ll}
\hline & KKTDI \\
\hline Monthly Average Consumption (Lecture Period) & $77,439[\mathrm{kWh}]$ \\
& $\mathrm{RM} 28,265.24$ \\
Monthly Average Consumption (Semester Break Period) & $41,107[\mathrm{kWh}]$ \\
& $\mathrm{RM} \mathrm{15,004.06}$ \\
& $21,482[\mathrm{kWh}]$ \\
Daily Average Consumption (Lecture Period) & $\mathrm{RM} 7,841.04$ \\
Daily Average Consumption (Semester Break Period) & $13,596[\mathrm{kWh}]$ \\
& $\mathrm{RM} \mathrm{4,962.43}$ \\
\hline
\end{tabular}

\subsection{Building Energy Index and Intensity}

Table 4 shows the building energy index for KKTDI calculated through Eq. (1). The annual consumption is normalized annual consumption which is derived from six month's data mentioned in the earlier section. The normalized annual consumption is calculated based on available six-month consumption data discussed in the earlier section with assumption that the other six months of the year will register similar consumption pattern.

Table 4

Building Energy Index

\begin{tabular}{ll}
\hline & KKTDI \\
\hline Annual Consumption (Normalized) & $654,976[\mathrm{kWh}]$ \\
Gross Floor Area & $28,599.52\left[\mathrm{~m}^{2}\right]$ \\
BEI & $22.90\left[\mathrm{kWh} / \mathrm{m}^{2}\right]$ \\
\hline
\end{tabular}

The building energy index recorded for KKTDI is at $22.90 \mathrm{kWh} / \mathrm{m}^{2}$ a year. The value is considered to be very low in comparison with $96.60 \mathrm{kWh} / \mathrm{m}^{2}$ a year for the overall campus. The main contribution towards this low value are the low occupancy rate, and less demanding space operational requirements. The low occupancy rate of KKTDI is shown in Table 2 with only 339 occupants in 
comparison with 1,244 available capacity which is only $27.25 \%$. Furthermore, the low value is also contributed by less demanding operational requirements. In comparison with most of other spaces in the university, the hostel area at the residential college are not equipped with air-conditioning system which is known to be main consumer of electricity in commercial buildings. Table 5 shows the energy intensity recorded for KKTDI using Eq. (2). The energy recorded energy intensity is at 1,932.08 $\mathrm{kWh}$ /occupant a year which is equivalent of RM 705.21/occupant a year.

Table 5

Energy Intensity

\begin{tabular}{ll}
\hline & KKTDI \\
\hline Annual Consumption (Normalized) & $654,976[\mathrm{kWh}]$ \\
Occupant Number & 339 [occupant] \\
Energy Intensity & $1,932.08$ [kWh/occupant] \\
\hline
\end{tabular}

\section{Conclusions}

The study aims to provide energy profile for residential college, KKTDI in terms of consumption profile, building energy index and energy intensity. The conclusions for present study are as follow

i. The average monthly consumption during semester period is $88.38 \%$ higher in comparison with consumption during semester break period.

ii. The monthly average electricity cost is at RM 28,265.24 and RM 15,004.06 during the semester period and semester break respectively.

iii. The building energy index and energy intensity for residential college are at 22.90 $\mathrm{kWh} / \mathrm{m}^{2} /$ year and $1,932.08 \mathrm{kWh}$ /occupant/year respectively.

\section{References}

[1] Council, E. "Directive 2010/31/EU of the European Parliament and of the Council of 19 May, 2010 on the energy performance of buildings." Official Journal of the European Union 153 (2010): 13-35.

[2] EIA, U.S. "International Energy Outlook 2013." Independent Statistics \& Analysis of U.S. EIA, 2013. http://www.eia.gov/forecasts/ieo/.

[3] Ahmad, Ahmad Sukri, Mohammad Yusri Hassan, Hayati Abdullah, Hasimah Abdul Rahman, Md Shah Majid, and Masilah Bandi. "Energy efficiency measurements in a Malaysian public university." In 2012 IEEE International Conference on Power and Energy (PECon), pp. 582-587. IEEE, 2012. https://doi.org/10.1109/PECon.2012.6450281

[4] Chua, Shing Chyi, and Tick Hui Oh. "Review on Malaysia's national energy developments: Key policies, agencies, programmes and international involvements." Renewable and Sustainable Energy Reviews 14, no. 9 (2010): 29162925. https://doi.org/10.1016/j.rser.2010.07.031

[5] Malaysia Energy Commission. "Peninsular Malaysia Electricity Supply Industry Outlook 2017." Suruhanjaya Tenaga Malaysia, 2017.

[6] Mohammad, Shahrul Nizam, Rozana Zakaria, Wahid Omar, Muhd Zaimi Abd Majid, Mushairry Mustaffar, Rosli Mohamad Zin, and Noor Azland Jainudin. "Potential of Solar Farm Development at UTM Campus for Generating Green Energy." Applied Mechanics and Materials $479 \quad$ (2013): 553-558. https://doi.org/10.4028/www.scientific.net/AMM.479-480.553

[7] Ltd., D\&R International. "2011 Buildings Energy Data Book." Buildings Technologies Program, Energy Efficiency and Renewable Energy, U.S. Department of Energy, 2011.

[8] Singh, Malkiat, Gurpreet Singh, and Harmandeep Singh. "Energy audit: A case study to reduce lighting cost." Asian Journal of Computer Science and Information Technology 2, no. 5 (2012): 119-122.

[9] Rathod, Deepak, Ranjana Khandare, and Asutosh Kumar Pandey. "Electrical Energy Audit (A Case Study Of Tobbaco Industry)." International Journal of Engineering 2, no. 3 (2013): 2305-8269.

[10] Worrell, Ernst, Lenny Bernstein, Joyashree Roy, Lynn Price, and Jochen Harnisch. "Industrial energy efficiency and climate change mitigation." Energy Efficiency 2, no. 2 (2009): 109-123. https://doi.org/10.1007/s12053-008-9032$\underline{8}$ 
[11] Prudenzi, Alberto, M. Di Lillo, A. Silvestri, and M. C. Falvo. "A software tool for energy audit activities in buildings." In 2008 International Symposium on Power Electronics, Electrical Drives, Automation and Motion, pp. 452-456. IEEE, 2008. https://doi.org/10.1109/SPEEDHAM.2008.4581295

[12] Choong, Weng Wai, Yin Fong Chong, and Sheau Ting Low. "Implementation of energy management key practices in Malaysian universities." International Journal of Emerging Sciences 2, no. 3 (2012): 455-477.

[13] Dahlan, Nur Dalilah, Phillip John Jones, Donald Kneale Alexander, E. Salleh, and J. Alias. "Evidence base prioritisation of indoor comfort perceptions in Malaysian typical multi-storey hostels." Building and Environment 44, no. 10 (2009): 2158-2165. https://doi.org/10.1016/i.buildenv.2009.03.010

[14] Jamaludin, Adi Ainurzaman. "Energy performance of three residential college buildings in University of Malaya campus, Kuala Lumpur." Journal of Design and Built Environment 9, no. 1 (2011): 59-73.

[15] Pfafferott, Jens Ü., Sebastian Herkel, Doreen E. Kalz, and Andreas Zeuschner. "Comparison of low-energy office buildings in summer using different thermal comfort criteria." Energy and Buildings 39, no. 7 (2007): $750-757$. https://doi.org/10.1016/i.enbuild.2007.02.005

[16] Wong, Nyuk Hien, D_K W. Cheong, H. Yan, J. Soh, C. L. Ong, and A. Sia. "The effects of rooftop garden on energy consumption of a commercial building in Singapore." Energy and Buildings 35, no. 4 (2003): 353-364. https://doi.org/10.1016/S0378-7788(02)00108-1

[17] Indraganti, Madhavi. "Adaptive use of natural ventilation for thermal comfort in Indian apartments." Building and Environment 45, no. 6 (2010): 1490-1507. https://doi.org/10.1016/j.buildenv.2009.12.013

[18] Mohit, Mohammad Abdul, Mansor Ibrahim, and Yong Razidah Rashid. "Assessment of residential satisfaction in newly designed public low-cost housing in Kuala Lumpur, Malaysia." Habitat International 34, no. 1 (2010): 18-27. https://doi.org/10.1016/i.habitatint.2009.04.002

[19] Iwaro, Joseph, and Abraham Mwasha. "Implications of building energy standard for sustainable energy efficient design in buildings." International Journal Energy Environment 1, no. 5 (2010): 745-756. 